\title{
Effect of niacin supplementation on performance and blood parameters of Holstein cows
}

\author{
K. Karkoodi ${ }^{\#}$ and K. Tamizrad \\ ${ }^{1}$ Department of Animal Science, Faculty of Agriculture, Islamic Azad University, Saveh-Branch, Saveh, Iran
}

\begin{abstract}
In this experiment the response to niacin supplementation was evaluated. Twelve multiparous Holstein cows were used in a replicated $4 \times 4$ Latin square statistical model in four $24 \mathrm{~d}$ periods as replicates. At the onset all the cows were in early lactation with days in milk (DIM) at $60.1 \pm 16.1$ and an average milk yield of $31.4 \pm 5.44 \mathrm{~L} / \mathrm{d}$. The treatments were: N0 - control (no niacin supplement); N1 - control + $12 \mathrm{~g}$ niacin/d; $\mathrm{N} 2$ - control $+14 \mathrm{~g}$ niacin/d and N3 - control $+16 \mathrm{~g}$ niacin/d. Means were compared with the Duncan's least range test. Milk yield, fat-corrected milk (FCM, 3.5\%) and total solids percentage (TS) were significantly higher in the $\mathrm{N} 2$ compared to the other treatments. There were no significant differences between treatments in milk fat and milk lactose percentages, but milk fat yield was significantly higher and milk fat percentage numerically higher in the N2 than in the other treatments. Milk protein yield and percentage were highest in N2, but milk protein percentage was not significantly different between the N2 and N1 treatments. Milk solids non-fat (SNF) percentage was the highest for N2. Evaluation of blood plasma parameters showed that $14 \mathrm{~g}$ niacin (N2) supplementation resulted in a significantly higher glucose concentration and the lowest Bhydroxybutyrate (BHBA) and nonesterified fatty acids (NEFA) concentrations as compared to the other treatments. This study suggested that the optimal level of niacin supplementation was $14 \mathrm{~g} \mathrm{niacin/cow} / \mathrm{d}$.
\end{abstract}

Keywords: Nicotinic acid, milk yield, milk composition, NEFA, BHBA, glucose and B vitamins

\#Corresponding author. E-mail: kkarkoodi@yahoo.com

\section{Introduction}

Vitamins are organic compounds that are essential for life but required in minute quantities. To date 14 vitamins have been discovered, though not all animal species require all of these 14 vitamins. Niacin is effective for early lactation cows that experience a negative energy balance (Weiss \& Gonzalo, 2006). Marginal deficiency symptoms of niacin are emaciation, reduced growth, milk production and reproduction, and increased susceptibility to infectious diseases (Weiss \& Gonzalo, 2006). The vitamins of the B complex perform key roles in the body as enzyme cofactors and/or metabolic agents, for example, about half the propionate that arrives at the ruminant liver is changed into glucose by enzymatic reactions that require Bvitamins such as biotin, niacin, pantothenic acid and riboflavin for this conversion (Schwab \& Shaver, 2004; Schwab \& Shaver, 2006). It has been well established that the B-vitamins are synthesized by the microflora in the rumen (Schwab \& Shaver, 2004; Schwab \& Shaver, 2006). However, niacin can also be synthesised in the body from tryptophan; requiring 34 to $86 \mathrm{mg}$ of tryptophan to synthesize $1 \mathrm{mg}$ of niacin (Firth \& Johnson, 1956; Goldsmith et al., 1961). Of all the vitamins, the dietary supply of vitamins A (ß-carotene) and $\mathrm{E}$ to dairy cattle is essential (Weiss \& Gonzalo, 2006). However, in recent years positive responses to the supplementation of some of the B vitamins in ruminants have been reported. It has been suggested that, due to the improvement in the genetic potential of dairy cows in recent years, their requirements tend to exceed the capacity of rumen microorganisms to synthesize sufficient vitamins of the B complex (Weiss \& Gonzalo, 2006).

Research has shown that niacin supplementation reduced non-esterified fatty acid (NEFA) and B-hydroxybutyric acid (BHBA) concentrations in the blood plasma of dairy cows by increasing the glucose levels in the serum (Dufva et al, 1983). One of the methods of preventing ketosis is the supplementation of niacin, and using it together with a glycogenic precursor such as propylene glycol or sodium propionate (Horwitt et al., 1981; Overton \& Waldron, 2004; Weiss \& Gonzalo, 2006). In some investigations (Jaster \& Ward, 1990; Young \& Smith, 1994) niacin supplementation during the transition period resulted in an increased milk production and milk fat percentage as well as a decrease in serum BHBA concentration (Dufva et al, 1983; Grummer, 1993; Minor et al, 1998). Fronk \& Schultz (1980) showed that nicotinic acid 
administration elicited some beneficial effects postpartum by increasing energy intake and inhibiting lipolysis. They illustrated that $12 \mathrm{~g} / \mathrm{d}$ of nicotinic acid increased both daily milk production and glucose, and decreased blood ketone bodies in cows affected by ketosis. In addition, an increased dosage level resulted in decreased NEFA concentrations in comparison to an unsupplemented control. Although the mechanism by which nicotinic acid or nicotinamide causes these changes in ruminants is not clearly defined, the ability of nicotinic acid to alleviate incidences of ketosis is related to its metabolic capacity to suppress NEFA mobilization from fat deposits and increased blood glucose concentrations. However, the cause of this increase is not clear, though could be related to increased blood glucose concentrations or reduced transition of blood glucose or both (Fronk \& Schultz, 1980). Minor et al. (1998) reported no effect of niacin supplementation to dairy cows before parturition on subsequent milk production, in spite of an improved energy and dry matter intake (DMI). In other investigations in which the effect of niacin supplementation was evaluated, it was concluded that niacin supplementation increased the production of fat-corrected milk (FCM, 3.5\%). They also reported increased serum glucose and decreased BHBA and NEFA concentrations (Fronk \& Schultz, 1980).

In some studies, niacin supplementation did not affect milk fat yield, milk protein yield or solid not fat (SNF) concentrations (Bernard et al., 1995; Doreau \& Ottou, 1996), though it has been suggested that the response is related to stage of lactation. A consequence of fat supplementation is a suppression of milk protein concentration. Niacin supplementation may alleviate the problem and increase milk protein yield (Driver et al., 1990; Young \& Smith, 1994; Rebecca et al., 1997). However, these results are not in agreement with some other reports (Bernard et al., 1995). Zimmerman et al. (1992) evaluated the effect of niacin supplementation together with level of acid detergent fibre (ADF) in the diet. This experiment showed that niacin supplementation increased blood glucose and decreased BHBA and NEFA concentrations. The objective of the present study was the evaluation of niacin supplementation at levels that have not been assessed in previous studies with dairy cows, to find an optimum level of supplementation.

\section{Materials and Methods}

Twelve multiparous Holstein cows were assigned to one of four diets in a complete randomized $4 \times 4$ Latin square experimental design in four $24 \mathrm{~d}$ periods as replicates. The average pre-experimental milk yield of the cows was $31.4 \pm 5.44 \mathrm{~L} /$ day, and all of cows were in early lactation $(60.1 \pm 16.1$ days in milk, DIM). A period in the experiment consisted of a 14-day adaptation period followed by a 10-day recording and sampling period. Treatments were: N0 - control (no niacin supplement); N1 - control diet plus $12 \mathrm{~g}$ niacin supplement/d; N2 - control diet plus $14 \mathrm{~g}$ niacin supplementation/d; N3 - control diet plus $16 \mathrm{~g}$ niacin supplement/d. Niacin was weighed on a digital scale and dosed orally. The composition of the control diet is shown in Table 1. This experimental diet was fed from 30 days before the start of the experiment to adapt the cows to the diet.

Milk samples were analyzed for milk lactose, fat, protein, total solid (TS) and solid non-fat (SNF) concentrations by the Milkoscan system (Foss Electric Hillerod, 133B Milkoscan, Denmark). Blood samples were centrifuged at $2000 \mathrm{rpm}$ for $10 \mathrm{~min}$ and plasma glucose, BHBA and NEFA concentrations were measured, using analytical kits (Man Company). Glucose concentration was measured using an enzymatic method with glucose oxidize (Man company, Iran), and BHBA concentration, using an UV method (RANDOX, cat no. RB 1007) that is based on the oxidation of BHBA to acetoacetate. NEFA concentration (RANDOX, cat no. FA 115 and 30 t) was analyzed with an enzymatic method in which the continuous change of enzymes resulted in $\mathrm{H}_{2} \mathrm{O}_{2}$ production.

The data was analysed by multiple regression analysis. The statistical model is as follows:

$$
\mathrm{Y}_{\mathrm{ijk} k m n}=\mu+\mathrm{R}_{\mathrm{i}}+\mathrm{C}_{\mathrm{j}}+\mathrm{T}_{\mathrm{k}}+\mathrm{M}_{\mathrm{l}}+\mathrm{RE}_{\mathrm{m}}+\mathrm{e}_{\mathrm{ijk} \mathrm{kmn}}
$$

Where $Y_{\mathrm{ijklm}}$ is the number of each observation; $\mu$ the total average; $R_{i}$ the effect of time period; $C_{j}$ the effect of diet; $T_{k}$ the effect of cow; $M_{1}$ the effect of square (replication of experiment); $R E_{m}$ the residual effect of previously fed diet and $\mathrm{e}_{\mathrm{ijk} k \mathrm{mn}}$ the effect of factors that were not controlled.

The cows were milked three times daily. During the experimental phase in each period, total milk yield was recorded for all cows and milk samples were taken. Potassium dichromate was added as a milk preservative (Hang \& Hayes, 1982). Blood samples were taken on the last day of each period. 
Data were analyzed using SAS (1999) statistical software, and residual effects of last ration were corrected. Comparison between means was done by the Duncan's multiple range test $(\alpha=0.05)$.

Table 1 Ingredients and nutrient composition of Control diet (DM basis)

\begin{tabular}{lcc}
\hline \multicolumn{1}{c}{ Item } & Diet & \% of diet \\
\hline Ingredients of diet (kg) & & \\
Lucerne hay & 6.135 & 30.01 \\
Maize silage & 3.415 & 16.71 \\
Maize grain & 2 & 9.78 \\
Barley grain & 3 & 14.68 \\
Linted cottonseed & 1.043 & 5.10 \\
Soyabean meal & 2.536 & 12.41 \\
Wheat bran & 2.024 & 9.90 \\
Sodium bicarbonate & 0.08 & 0.39 \\
Magnesium oxide & 0.03 & 0.15 \\
Mineral and vitamin supplements ${ }^{1}$ & 0.176 & 0.86 \\
Composition & & \\
NEL ${ }^{2}$, MJ/kg $/ \mathrm{kg}$ & 6.49 & \\
Crude protein, $\mathrm{g} / \mathrm{kg}$ & 153 & \\
Rumen degradable protein, $\mathrm{g} / \mathrm{kg}$ & 92.0 & \\
Undegradable protein $\mathrm{g} / \mathrm{kg}$ & 69.0 & \\
Neutral detergent fibre, $\mathrm{g} / \mathrm{kg}$ & 359 & \\
Acid detergent fibre, $\mathrm{g} / \mathrm{kg}$ & 213 & \\
Non fibre carbohydrates, $\mathrm{g} / \mathrm{kg}$ & 381 & \\
Ether extract, g/kg & 32.0 & \\
Calcium, g/kg & 6.20 & \\
Phosphorus, g/kg & 3.70 & \\
DCAD ${ }^{3}, \mathrm{mEq} / \mathrm{kg}$ & 350 & \\
& &
\end{tabular}

${ }^{1}$ Contained (per kilogram): 180 g Ca; 90 g P; 60 g Na; 19 g Mg; 2000 mg Fe; 300 mg Cu; 2000 mg Mn; 3000 mg $\mathrm{Zn} ; 10 \mathrm{mg} \mathrm{Se} ; 100 \mathrm{mg} \mathrm{Co,} 100 \mathrm{mg}$ I; $50 \times 10^{5} \mathrm{IU}$ vitamin A; $10 \times 10^{5} \mathrm{IU}$ vitamin D; 0.2 IU vitamin E.

${ }^{2}$ Net energy for lactation, calculated from NRC (2001).

Non fibre carbohydrates $=[100-(\mathrm{NDF} \%+\mathrm{CP} \%+\mathrm{EE} \%+$ ash $\%)]$.

${ }^{3}$ Dietary cation-anion difference $=\left(\mathrm{Na}^{+}+\mathrm{K}^{+}\right)-\left(\mathrm{Cl}^{-}+\mathrm{S}^{-}\right)$.

\section{Results and Discussion}

The response to niacin supplementation on milk yield and milk components is shown in Table 2. In this experiment there were differences $(\mathrm{P}<0.05)$ in milk and FCM yields between treatments. This is in agreement with other studies in which the highest level of niacin supplementation was $12 \mathrm{~g} / \mathrm{d}$ (Jaster \& Ward, 1990; Young \& Smith, 1994). Cows in these studies were in early lactation and had negative energy balances. However, these results are not in agreement with other reports (Driver et al., 1990; Christensen et al., 1992; Campbell et al., 1994; Bernard et al., 1995; Ottou et al., 1995), though, with the exception of one of these experiments, niacin was supplemented with a fat supplement or oilseeds. Campbell et al. (1994) evaluated the kinetics of niacin supplementation and its effect on lactation. It is important to note that the level of niacin supplement in their experiment was $12 \mathrm{~g} / \mathrm{d}$, the same as the second level (N2) of niacin supplementation in the present study. However, the cows in that experiment were not in early lactation. Our results showed that $14 \mathrm{~g}$ niacin/d (N2) had the greatest effect and the control the lowest means for FCM and milk yield.

In the present study there was no difference $(\mathrm{P}>0.05)$ in milk fat content between treatments. This is in agreement with most other research (Driver et al., 1990; Jaster \& Ward, 1990; Martinez et al., 1991; Christensen et al., 1992; Zimmerman et al., 1992; Campbell et al., 1994; Bernard et al., 1995; Ottou et al., 1995; Minor et al., 1998). However, Young \& Smith (1994) reported a difference $(\mathrm{P}<0.05)$ in milk fat content. They evaluated the effect of supplemental niacin with calcium salts of fatty acid and reported 
differences between niacin treatments. The low milk fat content in our study may be attributed to heat stress $\left(37 \pm 6^{\circ} \mathrm{c}\right)$ during the experimental period, and that early lactation cattle were used in the trial.

The milk protein percentage in treatment N2 $(14 \mathrm{~g}$ niacin/d) was higher $(\mathrm{P}<0.05)$ than in the control and N1 treatments. The same pattern was for N3 in comparison with the control and N1 $(\mathrm{P}<0.05)$. Also, the milk protein percentage in the N2 treatment was only numerically higher than in N3. These results were similar to those of Driver et al. (1990) and Christensen et al. (1992) in studies where niacin was supplied with a fat supplement. The major consequence of fat supplementation was a decreased milk protein yield, because niacin supplementation suppressed the effect of fat supplementation; though we observed that protein yield increased compared with the control (Table 2). Different results were observed in other studies (Martinez et al., 1991; Campbell et al., 1994; Ottou et al., 1995; Minor et al., 1998), though in these studies the niacin supplement was offered together with other supplements (Drackley, 1992, Driver et al., 1990; Erickson et al., 1990), or the cows were not in early lactation (Campbell et al., 1994; Ottou et al., 1995; Minor et al., 1998). Similar to other studies there was no significant difference $(\mathrm{P}>0.05)$ in milk protein percentage in the present study between $\mathrm{N} 1$ and the control. The highest milk protein percentage was recorded in the $\mathrm{N} 2$ and the lowest in the N1 treatments.

Niacin supplementation did not affect milk lactose concentration $(\mathrm{P}>0.05)$, in agreement with other research (Christensen et al., 1992; Bernard et al., 1995; Ottou et al., 1995; Minor et al., 1998).

In the present study total solid (TS) percentage in milk was not affected by niacin supplementation. This is not in agreement with the studies of Young \& Smith (1994), Bernard et al. (1995) and Minor et al. (1998) where niacin was supplemented with other ingredients such as calcium salt of fatty acids, non-fibre carbohydrates or heat-treated soyabeans. In one study, (Young \& Smith, 1994), the experimental cows were not in early lactation. The highest total milk solid percentage in the present study was found in treatment N2 (14 $\mathrm{g}$ niacin/d) and the lowest in the control.

Feeding $16 \mathrm{~g}$ niacin/d $(\mathrm{N} 3)$ resulted in a lower $(\mathrm{P}<0.05)$ solid non-fat $(\mathrm{SNF})$ percentage in milk than when $12 \mathrm{~g}$ niacin/d (N2) was fed. Although these results are not in agreement with those of Driver et al. (1990), Erickson et al. (1990), Bernard et al. (1995) and Doreau \& Ottou (1996), in two of these trials niacin supplement was offered alone, but some factors could have led to the inverse results, e.g. the cows were not in early lactation or level of niacin supplementation was not high enough to cause significant changes (Jaster \& Ward, 1990; Campbell et al., 1994). Furthermore, in some studies the niacin supplement was offered with other ingredients such as non-fibre carbohydrate sources (Martinez et al., 1991), and in another, rapeseed oil. Furthermore, the level of niacin supplementation $(6 \mathrm{~g} / \mathrm{d})$ could have been too low to be effective (Erickson et al., 1990).

The highest $(\mathrm{P}<0.05)$ milk fat yield was observed in the $14 \mathrm{~g}$ niacin/d treatment $(\mathrm{N} 2)$. Rebecca et al. (1997) reported an inverse result when $12 \mathrm{~g}$ niacin/d was fed.

Table 2 Mean milk yield (kg) and composition of the milk of dairy cows receiving different levels of niacin

\begin{tabular}{lcccc|c}
\hline & Control & \multicolumn{3}{c}{ Control diet } & \multicolumn{2}{c}{ s.e.m. } \\
\cline { 3 - 5 } & & +12 g Niacin & +14 g Niacin & \multicolumn{1}{c}{+16 g Niacin } \\
\hline Milk yield, $(\mathrm{kg})$ & $29.8^{\mathrm{d}}$ & $30.7^{\mathrm{c}}$ & $31.4^{\mathrm{a}}$ & $30.9^{\mathrm{b}}$ & 0.08 \\
FCM 3.5\%, (kg) & $24.5^{\mathrm{d}}$ & $25.4^{\mathrm{c}}$ & $26.9^{\mathrm{a}}$ & $25.5^{\mathrm{b}}$ & 0.07 \\
Fat, \% & 2.17 & 2.21 & 2.44 & 2.20 & 0.08 \\
Protein, \% & $2.79^{\mathrm{b}}$ & $2.76^{\mathrm{b}}$ & $2.95^{\mathrm{a}}$ & $2.90^{\mathrm{a}}$ & 0.04 \\
Lactose, \% & 4.96 & 5.17 & 5.22 & 5.23 & 0.06 \\
Total solids, \% & $10.8^{\mathrm{c}}$ & $10.7^{\mathrm{d}}$ & $11.0^{\mathrm{a}}$ & $10.9^{\mathrm{b}}$ & 0.08 \\
Solid non fat, \% & $8.59^{\mathrm{ab}}$ & $8.53^{\mathrm{ab}}$ & $8.78^{\mathrm{a}}$ & $8.48^{\mathrm{b}}$ & 0.08 \\
Fat yield, $(\mathrm{kg} / \mathrm{d})$ & $0.642^{\mathrm{c}}$ & $0.675^{\mathrm{b}}$ & $0.743^{\mathrm{a}}$ & $0.672^{\mathrm{b}}$ & 0.02 \\
Protein yield, $(\mathrm{kg} / \mathrm{d})$ & $0.828^{\mathrm{d}}$ & $0.843^{\mathrm{c}}$ & $0.925^{\mathrm{a}}$ & $0.893^{\mathrm{b}}$ & 0.02 \\
\hline
\end{tabular}

\footnotetext{
${ }^{\text {abcd }}$ Means with no common superscript in the same row differ significantly $(\mathrm{P}<0.05)$.

${ }^{*}$ FCM $(3.5 \%)=0.35$ Milk yield $(\mathrm{kg})+15[$ Fat yield $(\mathrm{kg})]$.
} 
Differences between milk protein yields $(\mathrm{P}<0.05)$ were recorded between all treatments. The highest protein yield was recorded in to the $\mathrm{N} 2(14 \mathrm{~g}$ niacin/d) treatment and the lowest in the control. This is in agreement with other research (Driver et al., 1990; Christensen et al., 1992; Young \& Smith, 1994). In their research the effect of niacin supplementation was evaluated with other ingredients (fat supplement, heattreated soyabean and calcium salts of fatty acids, respectively). Furthermore, except for one study (Young \& Smith, 1994), in two other trials the cows were in early lactation (Driver et al., 1990; Christensen et al., 1992). In studies where results differed from the present study (Jaster \& Ward, 1990; Martinez et al., 1991; Campbell et al., 1994; Bernard et al., 1995; Ottou et al., 1995) the niacin supplement was offered with other ingredients such as heat-treated soyabean, fat and rapeseed oil (Martinez et al., 1991; Bernard et al., 1995; Ottou et al., 1995). Further reasons for different results could be differences in stage of lactation (cows were not in early lactation) and low levels of niacin supplementation.

Data on blood parameters are shown in Table 3. The blood plasma glucose concentration was higher $(\mathrm{P}<0.05)$ in treatment, $\mathrm{N} 2(14 \mathrm{~g}$ niacin/d), compared to the control. This is in agreement with some other studies (Doreau \& Ottou, 1996), but differed from results reported by Driver et al. (1990), Christensen et al. (1992), Zimmerman et al. (1992), Young \& Smith (1994) and Minor et al. (1998). However, in all these studies the niacin supplement was offered with other ingredients such as fat supplement, protein and nonfibre carbohydrates. Furthermore, low levels of niacin supplementation and a later stage of lactation might have contributed to different results.

Table 3 Mean blood plasma sugar, plasma NEFA and plasma BHBA concentrations in dairy cows receiving different levels of dietary niacin

\begin{tabular}{lccccc}
\hline & Control & \multicolumn{3}{c}{ Control diet } & \multirow{2}{*}{ s.e.m. } \\
\cline { 3 - 4 } & & $+12 \mathrm{~g}$ Niacin & $+14 \mathrm{~g}$ Niacin & +16 g Niacin & \\
\hline \multirow{2}{*}{ Glucose, $\mathrm{mg} / \mathrm{dL}$} & $81.6^{\mathrm{b}}$ & $84.4^{\mathrm{ab}}$ & $85.8^{\mathrm{a}}$ & $85.0^{\mathrm{ab}}$ & 0.65 \\
BHBA, mmol/dL & $3.12^{\mathrm{a}}$ & $2.57^{\mathrm{ab}}$ & $2.27^{\mathrm{b}}$ & $2.71^{\mathrm{ab}}$ & 0.17 \\
NEFA, mmol/dL & $3.04^{\mathrm{a}}$ & $2.81^{\mathrm{ab}}$ & $2.32^{\mathrm{b}}$ & $2.67^{\mathrm{ab}}$ & 0.12 \\
\hline
\end{tabular}

The lowest concentrations of plasma BHBA and NEFA were found in cows on the N2 $(14 \mathrm{~g}$ niacin/d) treatment and the highest in the control. This is in agreement with the results of Schwab \& Shaver (2006b), but different from those reported by Driver et al. (1990), Campbell et al. (1994), Bernard et al. (1995) and Minor et al. (1998). The major reason may be related to stage of lactation, i.e. cows not in early lactation.

\section{Conclusions}

Niacin supplementation is most effective when cows are in early lactation. It is considered that niacin supplementation would reduce the harmful effects of a negative energy balance. Niacin supplementation may reduce metabolic disorders such as ketosis and fatty liver which can affect longevity and productivity in dairy cattle. Niacin may affect fat metabolism. However, fat metabolism is affected by hormonal regulations, too. Previous research on niacin supplementation evaluated responses at relatively low levels of supplementation, viz. $6 / \mathrm{d}$ and $12 \mathrm{~g}$ niacin/d. In the present study niacin supplementation was evaluated at higher levels and it was concluded that $14 \mathrm{~g}$ niacin/d was the most effective level of supplementation. Economic responses to the use of niacin supplementation and more research on the physiology of niacin responses are points that need further investigation.

\section{References}

Bernard, J.K., Quigley, J.D., Downlen, H.H. \& Lamar, K.C., 1995. Supplemental niacin and heat-treated whole soybeans for Jersey cows during early lactation. J. Dairy Sci. 78, 2016-2023.

Campbell, J.M., Murphy, M.R., Christensen, R.A. \& Overton, T.A., 1994. Kinetics of niacin supplements in lactating dairy cows. J. Dairy Sci. 77, 566-575. 
Christensen, R.A., Clark, J.H., Drackley, J.K. \& Blum, S.A., 1992. Effects of nicotinamide on energy and fatty acid utilization by lactating dairy cows. California Agriculture Fact Sheet. 22-25.

Doreau, M. \& Ottou, J.F., 1996. Influence of niacin supplementation on in vivo digestibility and ruminal digestion in dairy cows. J. Dairy Sci. 79, 2247-2254.

Drackley, J.K., 1992. Niacin and carnitine in the nutrition of dairy cows. Pacific NW Nutrition. Conference, Spokane, W.A., USA. p. 8.

Driver, L.S., Grummer, R.R. \& Schultz, L.H., 1990. Effects of feeding heat-treated soybeans and niacin to high producing cows in early lactation. J. Dairy Sci. 73, 463-469.

Dufva, G.S., Bartley, E.E., Dayton, A.D. \& Riddell, D.O., 1983. Effect of niacin supplementation on milk production and ketosis of dairy cattle. J. Dairy Sci. 66, 2329-2336.

Erickson, P.S., Murphy, M.R, Sweeny, M. \& Trusk, A.M., 1991. Niacin absorption from the rumen. J. Dairy Sci. 74, 3492-3495.

Firth, J. \& Johnson, B.C., 1956. Quantitative relationships of tryptophan and nicotinic acid in the baby pig. J. Nutr. 59, 223-234.

Fronk, T.J. \& Schultz, L.H., 1979. Oral nicotinic acid as a treatment for ketosis. J. Dairy Sci. 62, 1804-1807.

Fronk, T.J., Schultz, L.H. \& Hardie, A.R., 1980. Effect of dry period overconditioning of subsequent metabolic disorders and performance of dairy cows. J. Dairy Sci. 63, 1080-1090.

Goldsmith, G., Miller, O. \& Unglaub, W., 1961. Efficiency of tryptophan as a niacin precursor in man. J. Nutr. 73, 172-176.

Grummer, R.R., 1993. Etiology of lipid-related metabolic disorders in per parturient dairy cows. J. Dairy Sci. 76, 3882-3896.

Hang, N. \& Hayes, G.F., 1982. Effects of potassium dichromate and sample storage time on fat and protein by milko-scan and on protein and casein by a modified pro-milk MK II method. J. Dairy Sci. 65, 1895-1899.

Horwitt, M.K., Harper, A.E. \& Henderson, L.M., 1981. Niacin-tryptophan relationships for evaluating niacin equivalents. Am. J. Clin. Nutr. 34, 423-427.

Jaster, E.H. \& Ward, N.E., 1990. Supplemental nicotinic acid or nicotinamide for lactating dairy cows. J. Dairy Sci. 73, 2880-2887.

Martinez, N., Depeters, E.J. \& Bath, D.L., 1991. Supplemental niacin and fat effects on milk composition of lactating Holstein cows. J. Dairy Sci. 74, 202-210.

Minor, D.J., Trower, S.L., Strang, B.D., Shaver, R.D. \& Grummer, R.R., 1998. Effects of nonfiber carbohydrate and niacin on periparturient metabolic status and lactation of dairy cows. J. Dairy Sci. $81,189-200$.

NRC, 2001. Nutrient Requirements of Dairy Cattle. $7^{\text {th }}$ revised ed. National Research Council, National Academy Press, Washington, D.C., USA.

Ottou, J.F., Doreau, M.D. \& Chilliard, Y., 1995. Duodenal infusion of rapeseed oil in midlactation cow and interaction with niacin on dairy performance and nutritional balance. J. Dairy Sci. 78, 1345-1352.

Overton, T.R. \& Waldron, M.R., 2004. Nutritional management of transition dairy cows: strategies to optimize metabolic health. J. Dairy Sci. 87, 105-119.

Rebecca, J., Schingoeth, D.J., Brouk, M.J., Bear, R.J. \& Lentsch, M.R., 1997. Response of lactating cows to supplemental unsaturated fat and niacin. J. Dairy Sci. 80, 1329-1338.

SAS, 1999. SAS/STAT User's Guide, Version 8.01 ed. SAS Inst., Inc., Cary, N.C., USA.

Schwab, E.C. \& Shaver, R.D., 2004. B-Vitamin nutrition in dairy cows. J. Nutr. 25, 1346-1352.

Schwab, E.C. \& Shaver, R.D., 2006. B-Vitamin nutrition in dairy cows. J. Nutr. 35, 1326-1336.

Weiss, W.P. \& Gonzalo, F., 2006. Are your cows getting the vitamin they need? J. WCDS advances in Dairy Technology 18, 249-259.

Young, J.W. \& Smith, T.R., 1994. Effects of nicotinamide on milk composition and production in dairy cows fed supplemental fat. Antonio Research Fact Sheet. pp. 25-28.

Zimmerman, C.A., Rakes, A.H., Daniel, T.E. \& Hopkins, B.A., 1992. Influence of dietary protein and supplemental niacin on lactation performance of cows fed normal and low fibre diets. J. Dairy Sci. 75, 1965-1978. 